\title{
EVALUASI DAMPAK PROGRAM BROADBAND LEARNING CENTER DI TAMAN PRESTASI SURABAYA
}

\author{
Via Mega Arista \\ S1 Ilmu Administrasi Negara, Jurusan Administrasi Publik, Fakultas Ilmu Sosial dan Hukum \\ Universitas Negeri Surabaya \\ Viamegaarista07@gmail.com

\section{Indah Prabawati} \\ S1 Ilmu Administrasi Negara, Jurusan Administrasi Publik, Fakultas Ilmu Sosial dan Hukum \\ Universitas Negeri Surabaya \\ indahprabawati@unesa.ac.id
}

\begin{abstract}
Abstrak
Broadband Learning Center adalah program pelatihan komputer gratis yang disediakan oleh Pemerintah Kota Surabaya bertujuan untuk meningkatkan kemampuan dan produktivitas dalam penggunaan teknologi serta dilandasi pada isi Undang-undang Republik Indonesia Nomor 11 Tahun 2016 BAB II tentang Informasi dan Transaksi Elektronik. Dari 52 titik lokasi yang sudah menyebar di seluruh wilayah Surabaya salah satunya ada di Taman Prestasi Surabaya, masih terdapat kendala dalam pelaksanaannya seperti kurang meratanya informasi pelatihan kepada seluruh lapisan masyarakat dan kendala dalam pelaksanaan pelatihan. Tujuan penelitian ini untuk memberikan gambaran terkait dampak program Broadband Learning Center di Taman Prestasi Surabaya. Penelitian ini menggunakan pendekatan kualitatif dan menggunakan penelitian studi kepustakaan (library research) yang dimana data diperoleh dari literatur-literatur terkait evaluasi dampak Brodband Learning Center seperti makalah, artikel, jurnal dan berita dari website (internet). Hasil penelitian ini menyatakan bahwa program Broadband Learning Center di Taman Prestasi Surabaya berdampak pada individu dengan adanya kemudahan mendaftar dan meningkatkan kemampuan di bidang teknologi. Dampak pada organisasional yaitu adanya penghargaan untuk Pemerintah Kota Surabaya yang didapat melalui program Broadband Learning Center ini. Pelatihan ini juga berdampak pada peningkatan kepercayaan masyarakat terhadap instansi pemerintah dan berdampak pada lembaga sosial atau sistem sosial seperti lembaga pendidikan dan lembaga ekonomi. Saran dalam pelaksanaan Broadband Learning Center ini yaitu mensosialisasikan program secara berkala, mengupgrade sarana prasarana untuk pelatihan dan menambah variasi materi yang lain sehingga dapat menarik minat masyarakat.
\end{abstract}

Kata Kunci: Dampak, Broadband Learning Center, Pelatihan Komputer

\begin{abstract}
The Broadband Learning Center is a complimentary computer training program provided by the Surabaya Government which aims to increase capabilities and productivity in using technology and is based on Law of the Republic of Indonesia Number 11 of 2016 Chapter II concerning Electronic Information and Transactions. Of the 52 location points that have spread throughout the Surabaya area, one of them is located in Taman Prestasi Surabaya, there are still have obstacles such as the lack of even information about the Broadband Learning Center to all levels of society and constraints in the implementation of training. This research aims to provide an overview of the impact evaluation of the Broadband Learning Center program in Taman Prestasi. This research uses a qualitative approach and uses library research. The data is obtained from literature related to the impact evaluation of the Broadband Learning Center such as papers, articles, journals, and news from websites (internet). The results of this research state that the Broadband Learning Center program in Taman Prestasi Surabaya impacts individuals with the ease of registering and increasing skills in the field of technology. The organizational impact is an award for the Surabaya City Government obtained through the Broadband Learning Center program. This training also impacts increasing public trust in institutions government and impacts social institutions or social systems such as educational institutions and economic institutions. Suggestions on implementing the Broadband Learning Center are to regularly socialize the program, upgrade the infrastructure for training, and add a variety of other materials to attract public interest.
\end{abstract}

Keywords: Impact, Broadband Learning Center, Computer Training 


\section{PENDAHULUAN}

Di era keterbukaan informasi publik saat ini pemerintah sebagai penyedia layanan untuk masyarakat semakin dituntut untuk lebih maksimal dalam menjalankan peran dan fungsinya (Ulfa, 2016). Dalam pelayanan publik pemerintah menerapkan pelayanan berbasis teknologi atau E-Government. Pada salah satu negara di dunia yaitu Eropa menyadari pentingnya pelaksanaan E-Government dalam pelaksanaan pemerintahannya. Electronic government to make public institutions more transparent and accountable. Digital transformation in European countries took place in early 2006 and is currently implementing an E-Government (European Commission, 2016). Di Indonesia juga menerapkan teknologi informasi E-Government yang telah didukung melalui Instruksi Presiden RI Nomor 3 Tahun 2003 Tentang Kebijakan dan Strategi Nasional Pengembangan E-Government.

Teknologi Informasi dan Komunikasi (TIK) diharapkan dapat membantu meningkatkan potensi pada masyarakat dan dimanfaatkan oleh pemerintah dalam menangani permasalahan sosial yang kompleks (Kummitha, 2020). TIK tidak hanya untuk pemerintah dalam memaksimalkan pelayanan publik berbasis $E$ Government saja, tetapi juga harus dimanfaatkan secara optimal untuk meningkatkan kapasitas dalam individu masyarakatnya (Ariawantara, 2017).

Pada realitanya masyarakat salah satunya di Kota Surabaya masih belum memaksimalkan internet dengan produktif. Pada penelitian Amanah dari Guruku Hebat tahun 2019 yang berjudul Pemanfaatan Literasi Digital di Kalangan Guru dan Pelajar di Surabaya, menyatakan bahwa 78\% Pelajar di Surabaya lebih banyak memanfaatkan teknologi untuk mengakses media sosial (medsos) daripada mencari referensi tentang ilmu pengetahuan (Amanah, 2019). Pada penelitian lainnya yang dilakukan Perez dan Gomez mengenai bagaimana masyarakat menggunakan internet menjelaskan bahwa sebagian besar masyarakat memiliki akun media sosial yang setiap hari diakses setidaknya menghabiskan waktu 30 menit perhari (Perez dan Gomez, 2012).

Adanya permasalahan umum penggunaan TIK dan internet baik di dunia maupun Indonesia khususnya di Kota Surabaya tersebut, maka Pemerintah Kota Surabaya membuat inovasi program pelatihan komputer gratis yang dinamai Broadband Learning Center (BLC). Program BLC ini ditetapkan pada tahun 2006 oleh PT. Telkom, tetapi pada tahun 2012 di hibahkan kepada Pemerintah Kota Surabaya. Tujuan PT. Telkom menghibahkan program ini karena untuk bekerja sama dalam membantu memaksimalkan pelayanan publik di bidang pendidikan dan teknologi. Penyerahan ini tertuang pada Naskah
Perjanjian Hibah Daerah antara PT. Telekomunikasi Indonesia, Tbk. dengan Pemerintah Kota Surabaya berupa penyediaan fasilitas layanan publik berbasis teknologi informasi Nomor 415.4 / 2091/ 436.2.3/ 2010 (Mulyasari dan Rosdiana, 2017).

Tujuan program BLC ini tercantum dalam website resmi blc.surabaya.go.id untuk mewujudkan masyarakat agar melek IT dengan memberikan sarana dan prasarana pembelajaran telematika secara gratis dan bersertifikat tanpa melihat berapa usia peserta, gender, lokasi tempat tinggal, kondisi sosial ekonomi ataupun pengalaman pendidikan peserta BLC.

BLC dilengkapi dengan fasilitas pendukung lainnya seperti wifi gratis dan instruktur dalam membimbing peserta. Instruktur BLC disediakan oleh Dinas Komunikasi dan Informatika Surabaya dan diberikan pelatihan terlebih dahulu agar instruktur paham terkait materi yang akan disampaikan kepada peserta BLC nantinya. Materi yang ada di BLC ini yaitu materi aplikasi administrasi perkantoran, materi desain grafis dan materi internet. Materi-materi ini disesuaikan dengan jenjang pendidikan peserta dan instruktur menyesuaikan agar output yang diharapkan dapat tercapai.

Program BLC ini telah memiliki 52 titik lokasi yang sudah menyebar di seluruh wilayah Surabaya. Salah satu lokasinya terletak di Taman Prestasi Surabaya. Lokasi tersebut diresmikan pada tahun 2012. Lokasi ini cukup strategis karena bertempat di tengah Kota Surabaya di Jalan Ketabang Kali Kecamatan Genteng Surabaya. Taman Prestasi ini selain menyediakan tempat rekreasi dan sarana permainan bagi masyarakat tetapi juga menyediakan tempat edukasi berupa pelatihan komputer agar masyarakat dapat memiliki kompetensi di bidang teknologi.

Dalam mengimplementasikan suatu program terdapat kendala atau hambatan yang akan ditemui. Perlu adanya indikator dalam menjalankan suatu program agar dapat mengetahui keberhasilan program atau kebijakan tersebut. Menurut Maarse (1987) program dikatakan berhasil karena ditentukan dari isi kebijakan tersebut, informasi dari para pelaksana atau aktor yang terlibat dalam implementasi program sehingga program tersebut dapat berjalan dengan optimal, kemudian perlu adanya dukungan yang harus dimiliki agar kebijakan dapat di laksanakan. Salah satu program yang ditemui kendala dalam pelaksanaanya yaitu pada BLC di Surabaya.

Program BLC ini dibuat agar masyarakat terutama di Kota Surabaya dapat menggunakan teknologi dengan baik sehingga memberikan manfaat bagi mereka, tetapi pola pikir dari beberapa masyarakat menganggap pelatihan BLC ini hanya bermanfaat bagi siswa sekolah saja. Statement tersebut dibuktikan pada penelitian yang dilakukan oleh Febriany dan Fanida bahwa kurangnya 
partisipasi masyarakat untuk mengikuti pelatihan BLC dipengaruhi oleh pola pikir tersebut (Febriany dan Fanida, 2015). Hal itu juga dibuktikan pada data jumlah peserta BLC bahwa terdapat banyak perbedaan disetiap kategori pekerjaannya, data tersebut dapat dilihat pada tabel 1 berikut ini :

Tabel 1. Jumlah Peserta BLC Berdasarkan Pekerjaan di Tahun 2017

\begin{tabular}{|c|c|c|}
\hline No. & $\begin{array}{c}\text { Kategori } \\
\text { Pekerjaan }\end{array}$ & Jumlah Peserta \\
\hline 1. & Sekolah Dasar (SD) & 51.899 \\
\hline 2. & $\begin{array}{l}\text { Sekolah Lanjutan Tingkat } \\
\text { Pertama (SLTP) }\end{array}$ & 9.355 \\
\hline 3. & $\begin{array}{l}\text { Sekolah Lanjutan Tingkat } \\
\text { Atas (SLTA) }\end{array}$ & 6.968 \\
\hline 4. & Perguruan Tinggi & 3.678 \\
\hline 5. & $\begin{array}{l}\text { Usaha Kecil dan } \\
\text { Menengah (UKM) }\end{array}$ & 2.958 \\
\hline 6. & $\begin{array}{l}\text { Pembinaan Kesejahteraan } \\
\text { Keluarga (PKK) }\end{array}$ & 4.361 \\
\hline 7. & Bunda PAUD & 13.535 \\
\hline 8. & Kader Lansia & 20 \\
\hline 9. & Karang Taruna & 562 \\
\hline 10. & $\begin{array}{l}\text { Badan Keswadayaan } \\
\text { Masyarakat (BKM) }\end{array}$ & 82 \\
\hline 11. & $\begin{array}{l}\text { Institusi Masyarakat } \\
\text { Pedesaan (IMP) }\end{array}$ & 168 \\
\hline 12. & $\begin{array}{l}\text { Pegawai Negeri Sipil } \\
\text { (PNS) }\end{array}$ & 1.911 \\
\hline 13. & Karyawan Swasta & 9.448 \\
\hline 14. & Guru & 10.571 \\
\hline 15. & Wiraswasta & 3.392 \\
\hline 16. & Belum Bekerja & 3.142 \\
\hline 17. & Pensiunan & 1.385 \\
\hline 18. & RT RW & 70 \\
\hline 19. & Ibu Rumah Tangga & 13.588 \\
\hline \multicolumn{2}{|r|}{ Total } & 137.092 \\
\hline
\end{tabular}

Pada data diatas peserta BLC di tahun 2017 lebih banyak diikuti jenjang Sekolah Dasar mencapai 51.899 peserta dan kurang diikuti oleh peserta kader lansia yang hanya 20 peserta saja. Berdasarkan tabel tersebut dapat dikatakan terdapat diferensiasi peserta yang belum merata.

Tujuan program BLC yang terletak di Taman Prestasi Surabaya ini salah satunya untuk sarana belajar masyarakat Surabaya untuk menyadari pentingnya teknologi informasi. Program ini diharapkan dapat berdampak pada seluruh lapisan masyarakat Surabaya sehingga mereka dapat mempelajari pemanfaatan teknologi informasi dan komunikasi tanpa ada jenjang usia atau pekerjaan. BLC di Taman Prestasi Surabaya telah memberikan fasilitas serta melaksanakan pelatihan dengan rutin, tetapi pada data pengunjung BLC Prestasi Surabaya tahun 2014 sampai 2016 cenderung menurun. Data ini dijelaskan pada penelitian Muryani,dkk bahwa pengunjung BLC di Taman Prestasi mulai tahun 2014 menurun (Muryani dkk, 2017). Data tersebut dapat dilihat pada grafik 1 berikut ini :

\section{Grafik 1. Data Pengunjung BLC Taman Prestasi di Tahun 2014-2016}

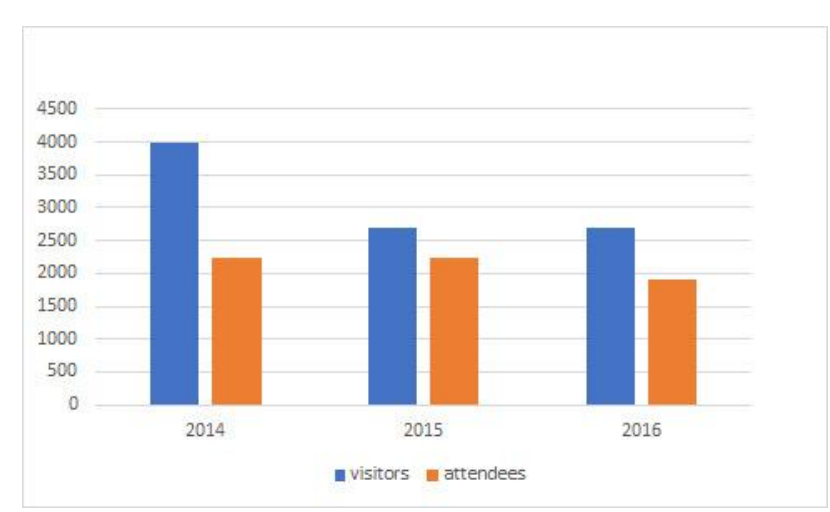

Sumber : Muryani,dkk (2017)

Permasalahan dalam implementasi program BLC di lokasi Taman Prestasi Surabaya lainnya terdapat pada jurnal Ulfa yang berjudul Pelaksanaan Program Broadband Learning Center (BLC) Oleh Dinas Kominfo Pemkot Surabaya Untuk Mewujudkan Surabaya Cyber City. Pada wawancaranya dengan salah satu peserta BLC di taman Prestasi Surabaya yaitu Sudjono berusia 50 tahun mengakui bahwa :

"selama ini sudah ada upaya sosialisasi yang telah dilakukan oleh Diskominfo Kota Surabaya untuk mempromosikan program ini dengan menyampaikan melaui kecamatan atau balaibalai RW tetapi belum menjangkau semua lapisan masyarakat" (Ulfa, 2016).

Sosialisasi juga telah dilakukan oleh instruktur BLC dan Diskominfo Kota Surabaya melalui media sosial tetapi karena dukungan dari RT mapun RW dirasa kurang sehingga membuat masyarakat tidak tertarik untuk bergabung dalam pelatihan di BLC (Vionita dan Rahaju, 2016).

BLC di Taman Prestasi Surabaya tidak hanya memiliki permasalahan kurangnya sosialisasi saja, tetapi terkait fasilitas yang belum di upgrade, kecepatan akses internet yang juga kurang maksimal sehingga dalam melaksanakan kegiatan pembelajaran terkendala dengan jaringan internet, dan belum ada modul resmi untuk 
peserta pelatihan sebagai pegangan awal dalam pembelajaran di BLC (Ulfa, 2016).

Permasalahan yang akan dijawab dalam penelitian ini yaitu bagaimana evaluasi dampak program Broadband Learning Center di Taman Prestasi Surabaya. Dalam sebuah kebijakan atau program dikatakan berhasil jika kebijakan atau program tersebut saat di implementasikan memberikan dampak yang diinginkan oleh para pelaksana dan masyarakat. Dampak dapat diartikan sebagai akibat atau konsekuensi yang ditimbulkan dari kebijakan atau program yang telah dilaksanakan. Dampak dapat dirasakan dari perubahan sikap masyarakat setelah menjalankan kebijakan atau program tersebut (Islamy, 2007).

Menurut Wibawa, dampak kebijakan atau program dirasakan oleh beberapa unit sosial (Wibawa, 1994) seperti :

1. Dampak yang dirasakan pada individual yang dapat menyentuh beberapa aspek seperti : (a) Dampak pada psikis; (b) Dampak pada lingkungan; (c) Dampak pada ekonomi; (d) Dampak sosial dan personal.

2. Dampak organisasional. Program BLC dapat dirasakan oleh suatu organisasi atau kelompok terutama pada Pemerintah Kota Surabaya sebagai pelaksana program ini, baik secara langsung maupun tidak langsung. Dampak langsung dapat berupa terganggu atau terbentuknya pencapaian tujuan organisasi atau kelompok. Sementara itu suatu kebijakan juga dapat menimbulkan dampak tak langsung terhadap sebuah organisasi atau kelompok, misalnya melalui semangat belajar atau kerja dari suatu kelompok itu sendiri.

3. Dampak masyarakat. Dampak tentunya dapat dirasakan pada masyarakat sebagai kelompok sasaran dalam suatu kebijakan atau program, seperti menunjukkan apakah keberadaan program BLC ini di tengah masyarakat dapat mempengaruhi masyarakat tersebut.

4. Dampak pada lembaga dari sistem sosial. Dampak ini dimaksudkan untuk mengetahui apakah pelaksanaan program BLC selama ini dapat mempengaruhi beberapa lembaga dan berbagai dimensi sosial lainnya.

Alasan penelitian ini menggunakan teori Samodra Wibawa tentang evaluasi dampak karena lebih memfokuskan pada outcome dibandingkan pada proses pelaksanaannya, sehingga dalam mengevaluasi dampak program BLC di Taman Prestasi Surabaya sesuai berdasarkan kriteria atau indikator yang ada dalam teori tersebut.

Tujuan penelitian untuk mendeskripsikan dampak dari pelaksanaan program BLC di Taman Prestasi Surabaya dengan melihat implementasi dan hasil pelatihan komputer gratis yang dilakukan di Taman Prestasi agar mampu mengetahui pencapaian (keluaran/ hasil/ dampak) program Broadband Learning Center apakah dengan program ini mampu mengatasi masalah yang ada, khusunya terkait permasalahan Teknologi Informasi dan Komunikasi (TIK) di Surabaya.

Manfaat penelitian ini secara teoritis diharapkan dapat memberikan sumbangsih pemikiran terhadap perkembangan ilmu pengetahuan di Program Studi Ilmu Adminitrasi Negara khususnya mengenai evaluasi dampak pada suatu program. Secara praktis dapat memberikan suatu informasi mengenai pelaksanaan program BLC khususnya di Taman Prestasi Surabaya dalam upaya mencapai tujuannya dan memberikan saran untuk meningkatkan kinerja pelayanan program BLC di kemudian hari.

\section{METODE}

Pada penelitian ini menggunakan pendekatan kualitatif dan menggunakan penelitian studi kepustakaan (library research) yang bertujuan untuk mendiskripsikan evaluasi dampak program Broadband Learning Center di Taman Prestasi Surabaya. Pada penelitian ini menggunakan sumber data sekunder yang diperoleh dari literatur sesuai dengan topik pembahasan seperti makalah, artikel, jurnal dan berita dari website (internet). Teknik pengumpulan data dengan mengidentifikasi beberapa makalah atau artikel, jurnal, website (internet), atau informasi lainnya yang berhubungan dengan BLC untuk mencari hal-hal atau variabel yang berupa catatan, transkip, buku, surat kabar, majalah dan sebagainya. Teknik yang diambil pada penelitian ini yaitu model Miles dan Huberman. Dalam model ini dilakukan secara interaktif dan terus menerus sampai dirasa cukup.

Ada dua tahap dalam teknik analisis data pada penelitian kepustakaan (library research) ini. Pertama, analisis pada saat pengumpulan data yang di tunjukan untuk lebih menangkap inti dari fokus penelitian yang akan dilakukan melalui sumber-sumber yang telah dikumpulkan. Kedua, menganalisis kembali setelah data terkumpul yang berupa data mentah yang harus ditentukan hubungan satu sama lain (Kaelan, 2010).

Aktifitas analisis data model ini diantaranya adalah reduksi data (data reduction), display data dan gambaran konklusi atau verifikasi (conclusion drawing/verification).

\section{HASIL DAN PEMBAHASAN}

Broadband Learning Center merupakan program Pemerintah Kota Surabaya yang menyediakan pelatihan komputer gratis. Program BLC ini ditetapkan pada tahun 2006 oleh PT. Telkom, tetapi pada tahun 2012 di hibahkan kepada Pemerintah Kota Surabaya. Tujuan PT. Telkom menghibahkan program ini karena untuk bekerja sama dalam membantu memaksimalkan pelayanan publik di bidang pendidikan dan teknologi. Penyerahan ini tertuang pada Naskah Perjanjian Hibah Daerah antara PT. 
Telekomunikasi Indonesia, Tbk. dengan Pemerintah Kota Surabaya berupa penyediaan fasilitas layanan publik berbasis teknologi informasi Nomor 415.4 / 2091/ 436.2.3/ 2010 .

Tujuan program ini juga dilandasi pada isi Undangundang Republik Indonesia tentang Informasi dan Transaksi Elektronik Nomor 11 Tahun 2016 BAB II pada pasal 4 yaitu: Pemanfaatan Teknologi Informasi dan Transaksi Elektronik dilaksanakan dengan tujuan (a) mencerdaskan kehidupan bangsa sebagai bagian dari masyarakat informasi dunia; (b) mengembangkan perdagangan dan perekonomian nasional dalam rangka meningkatkan kesejahteraan masyarakat; (c) meningkatkan efektivitas dan efesiensi pelayanan publik; (d) membuka kesempatan seluas-luasnya kepada setiap orang untuk memajukan pemikiran dan kemampuan di bidang penggunaan dan pemanfaatan teknologi informasi seoptimal mungkin dan bertanggung jawab; (e) memberikan rasa aman, keadilan, dan kepastian hukum bagi pengguna dan penyelenggara teknologi informasi.

Pada pelaksanaan program BLC selama ini tentu memberikan dampak terhadap individu, organisasi, masyarakat dan lembaga sosial baik secara langsung maupun tidak langsung.

\section{A. Dampak Individual}

Broadband Learning Center adalah program yang memberikan kemudahan dalam mempelajari TIK. Dalam mempelajari TIK terdapat banyak dampak yang diberikan seperti pada sosial ekonomi. Pada jurnal yang menjelaskan dampak penggunaan teknologi digital terhadap pertumbuhan ekonomi di Afrika menyimpulkan bahwa TIK mampu memberikan perubahan dalam pembangunan sosial dan ekonomi (Solomon dan Klyton, 2020). Sehingga program BLC yang salah satunya berada di lokasi Taman Prestasi Surabaya juga memiliki dampak individual dari aspek psikis, sosial ekonomi maupun lingkungan karena telah memberikan pelatihan TIK atau komputer gratis bagi masyarakat.

Dampak individual yang dirasakan dalam pelaksanaan BLC secara psikis adalah masyarakat menerima keberadaan program ini sebagai salah satu pelayanan publik yang diberikan pemerintah dengan dibuktikan jumlah peserta yang ikut dalam BLC. Dengan adanya BLC setiap individu mampu meningkatkan potensi dalam bidang teknologi. Program ini memberikan pelatihan komputer gratis untuk setiap masyarakat tanpa memandang umur atau jenjang pekerjaan sehingga mempermudah setiap individu mengembangkan kopetensinya di bidang teknologi. Hasil penelitian oleh Mulyasari dan Rosdiana mengenai dampak program BLC di lokasi Kelurahan pada Dukuh Manunggal Surabaya menjelaskan bahwa keberadaan BLC disana disambut dengan baik dari anak sekolah sampai ibu rumah tangga. Pada penelitian itu juga menjelaskan dengan adanya keberadaan pelatihan komputer gratis di daerah tersebut, setiap individu yang mengikuti jalannya pelatihan BLC mendapatkan suatu perubahan dari yang tidak bisa mengoperasikan IT menjadi bisa (Mulyasari dan Rosdiana, 2017).

Kemudahan dalam mengakses program BLC ini juga menjadi salah satu yang dirasakan peserta, seperti kemudahan cara mendaftarkan diri untuk melaksanakan pelatihan komputer tersebut. Pendaftaran peserta dapat melalui website resmi BLC yaitu blc. Surabaya.go.id atau langsung ke lokasi BLC salah satunya di Taman Prestasi Surabaya ini. Syarat dalam mendaftarkan diri, setiap calon peserta wajib mengisi lembar formulir yang sudah disediakan, mengumpulkan Kartu Tanda Penduduk (KTP) atau Kartu Keluarga (KK), mengumpulkan pas foto $4 \times 6$ sebanyak dua lembar dan melakukan pre test untuk mengetahui kemampuan calon pesertanya (Mufliha, 2018).

Masyarakat menerima program yang diberikan ini tidak hanya karena pemanfaatannya dan cara mendaftar yang mudah tetapi ketersediaan fasilitas yang menunjang pembelajaran dan memenuhi standar pelayanan yang baik bagi masyarakat meskipun tidak dipungut biaya. Fasilitas BLC di Taman Prestasi Surabaya meliputi 10 unit komputer, $A C$, Papan Tulis, Rak buku atau perlengkapan, printer,dispenser, speaker, lcd/proyektor, meja pengajaran, alat kebersihan, dan toilet. Pelatihan BLC juga rutin dilaksanakan dari hari Senin sampa hari Jumat dan setiap harinya memiliki 5 sesi pelatihan.

Pada program BLC ini menyediakan materi berbasis kebutuhan peserta tingkat dasar, menengah dan lanjut seperti: (a) Aplikasi perkantoran yang menjelaskan terkait penulisan karya ilmiah atau skripsi, surat atau undangan resmi, perhitungan keuangan, presentasi usaha; (b) Internet For Education yang mempelajari Kuesioner Online, Google Drive dan Jurnal Online; (c) Internet For Business yang menjelaskan terkait pemasaran sosial media dan marketplace lokal Surabaya; (d) Desain Grafis dan Video Edit menjelaskan berbagai desain kemasan, poster, kartu nama, stiker, brosur, editing foto juga video, dan yang terakhir yaitu; (e) Fun Programming tentang Logika Dasar yang akan dijelaskan kepada peserta BLC.

Materi yang diberikan oleh instruktur BLC kepada peserta hanya diperbolehkan mengambil satu materi dalam sekali periode. Ketentuan tersebut diharapkan berdampak pada peserta agar lebih mengoptimalkan pembelajaran yang diterima. Peserta BLC juga dapat memilih materi yang sesuai dengan bidang yang diminati sehingga setiap peserta dapat fokus mempelajari materi tersebut. Menurut Davis (dalam Sutarto, 2012:3) pelatihan adalah proses untuk mengembangkan ketrampilan dan 
membantu individu atau kelompok dalam suatu organisasi agar lebih efektif dan efesien didalam menjalankan pekerjaan. Dari teori tersebut menjelaskan bahwa dengan pelatihan mempermudah setiap individu atau kelompok dalam meningkatkan kualitasnya, salah satunya dalam pelatihan BLC ini yang memberikan kemudahan untuk setiap masyarakat dalam meningkatkan dirinya di bidang teknologi.

Dampak ekonomi dari program BLC dirasa cukup mempengaruhi karena dengan adanya materi yang berhubungan dengan bisnis secara online memberikan kemudahan dalam meningkatkan perokonomian peserta BLC. Pada skripsi yang ditulis oleh Putri menyebutkan bentuk wawancaranya oleh Wiwien bahwa :

\begin{abstract}
"salah satu masyarakat sebagai peserta BLC yang mengaku senang karena telah dibangunnya BLC di Taman Prestasi Surabaya. Rasa senang yang timbul dari peserta BLC tersebut karena sebelumnya yang tidak pernah mengakses internet sekarang dapat mengoprasikannya dan mulai merintis usaha dengan menggunakan jaringan internet “(Putri, 2014).
\end{abstract}

Jika peserta BLC yang memanfaatkan hal tersebut maka dampak ekonomi yang dirasakan cukup besar.

Program BLC selama pelaksanaannya juga memberikan dampak lingkungan seperti salah satunya lingkungan guru yang dimana pada penelitian yang dilakukan Rusmawati dan Nurus tahun 2016 bahwa dengan adanya pelatihan BLC ini berpengaruh terhadap Kompetensi Guru Sekolah Menengah Kejuruan (SMK) Swasta di Surabaya Barat (Rusmawati dan Safa'atillah, 2016). Tidak hanya di lingkungan guru, Rusmawati dan Nurus juga menjelaskan pengaruh cukup besar dari pelatihan BLC terhadap kinerja Pegawai Negeri Sipil (PNS) di wilayah Kecamatan Benowo Kota Surabaya (Rusmawati dan Safa'atillah, 2017). Dengan hal ini pelaksanaan BLC salah satunya di Taman Prestasi Surabaya memberikan dampak yang dirasakan setiap lingkungan masyarakat.

Dengan adanya pelatihan Menurut Goldstein dan Gressner (1988) dalam Kamil (2012) sebagai salah satu usaha dalam membantu meningkatkan ketrampilan dan berdampak pada peningkatan kinerja. Dalam menjalankan pelatihan akan mendapatkan sebuah pengalaman dan memperoleh pendidikan berupa ilmu serta dapat dijadikan salah satu inventasi pada diri peserta. Dengan adanya pelatihan juga melatih interaksi dengan peserta lain atau lingkungan sosial kemasyarakatan disekitarnya (Kamil, 2012)

Manfaat pelatihan ini menurut Noe dkk. jika dikaitkan dengan program BLC adalah (a) meningkatkan pengetahuan pada peserta di bidang teknologi informasi dan komunikasi; (b) membantu peserta untuk meningkatkan kemampuannya dalam bekerja menggunakan internet atau teknologi; (c) membantu peserta untuk lebih efektif dalam bekerja atau belajar sehingga dapat menghasilkan jasa atau produk yang lebih maksimal. Dengan manfaat yang di berikan dalam pelatihan BLC dapat membantu para pelaku Usaha Mikro, Kecil dan Menengah (UMKM). BLC ini berdampak pada pelaku UMKM di Surabaya karena dapat memanfaatkan internet untuk memperluas jangkauan pasarnya.

Dalam sebuah program, selain memberikan dampak yang diharapkan oleh masyarakat atau pembuat program tersebut, ada pula dampak yang timbul tetapi tidak diharapkan. Dampak yang tidak diharapkan dalam pelaksanaan program BLC ini adanya pro dan kontra yang disampaikan oleh koordinator BLC yang juga menjadi mentor BLC dalam skripsi yang ditulis oleh Putri, bahwa terdapat kecemasan orang tua terhadap anaknya jika mengikuti pelatihan internet ini memberikan banyak peluang untuk membuka hal yang dilarang melalui smartphone atau perangkat komputer lainnya dan menggunakan internet terus-menerus sehinngga menurunkan minat membaca buku di perpustakan (Putri, 2014).

Pelaksanaan pelatihan BLC ini juga memiliki kendala seperti kurangnya motivasi masyarakat dalam melanjutkan setiap sesi pertemuan. Pada bulan Februari hingga Maret Tahun 2015 terdapat penurunan dalam daftar hadir peserta BLC di Taman Prestasi Surabaya dari 175 dari 20 kali pertemuan menjadi 156 dari 20 kali pertemuan (Hakim, 2015).

Menurut Notoatmodjojo menyatakan bahwa implementasi program pelatihan dapat dikatakan berhasil mencapai tujuannya jika setiap peserta yang melaksanakan pelatihan memberikan suatu perubahan atau peningkatan kemampuan dalam melaksanakan tugas dan peningkatan kinerjanya seperti sikap disiplin atau etos dalam bekerja (Notoatmodjojo,2003). Sehingga dampak dari pelatihan BLC ini dapat dirasakan pada setiap individu yang menjadi peserta pelatihan. Salah satu dampak yang dirasakan setelah mengikuti pelatihan di BLC Taman Prestasi yaitu Mariani sebagai pelaku usaha mengaku bahwa:

"BLC sangat bermanfaat dan dapat menambah ilmu serta bisa jualan online. Dari yang tidak bisa apa-apa, menjadi bisa" (blc.surabaya.go.id).

\section{B. Dampak Organisasional}

Dampak organisasi dari suatu program atau kebijakan yaitu membantu atau tidaknya pencapaian tujuan-tujuan organisasi tersebut. Dalam suatu program atau kebijakan memberikan dampak baik secara langsung atau tidak 
langsung terhadap organiasasi. Dampak secara langsung seperti terbantu atau terganggunya organisasi tersebut dalam mencapai tujuannya. Sementara dampak tidak langsung seperti peningkatan semangat kerja dari anggota organisasi tersebut (Wibawa, 1994) .

Sasaran program BLC ini sebagai upaya mewujudkan Surabaya Multi Media City yaitu: (a) Surabaya Broadband Government and Education (B-GovEd), yang merupakan wahana pelatihan pemanfaatan TIK secara selektif bagi UKM, pelajar SD, SLTP, dan SLTA di Kota Surabaya; (b) Surabaya Broadband Citizen, yang merupakan layanan free Hot Spot dan informasi di beberapa lokasi yang telah disepakati; (c) Surabaya Government Community, yang merupakan layanan informasi dan media pembelajaran telematika yang berbasis internet di lokasi Hot Spot (Ariawantara, 2017).

Dari pelaksanaan BLC memberikan dampak pada organisasi contohnya pada tesis yang dilakukan Hidayatullah tentang Respon Pemuda Islam Terhadap Program BLC ini di Surabaya, menjelaskan manfaat BLC untuk lingkungan Remaja Masjid (REMAS) karena dengan program ini membantu kegiatan REMAS lebih efektif dan efesien dalam penyebaran informasi dan meminimalisir kesalahan karena menggunakan teknologi (Hidayatullah, 2017). Dampak BLC tidak hanya dirasakan pada organiasi yang mengikuti pelatihan saja, tetapi ada pula dampak yang dirasakan pada organisasi yang melaksanakan program ini yaitu pada tahun 2013 Pemerintahan Kota Surabaya mendapatkan penghargaan FutureGov Awards Asia Pasific 2013. Dalam website resmi Kementrian Komunikasi dan Informatika Republik Indonesia Kota Surabaya memperoleh penghargaan data inclusion yang didapat melalui program BLC yang bertujuan mengatasi kesenjangan digital. Penghargaan juga didapatkan Kota Surabaya dari Indonesian Digital Society Award (IDSA) dengan menyandang juara 1 best of the best dan e-government pada tahun 2015 (Eprilianto dkk, 2019).

Pada Jurnal penelitian yang ditulis oleh Bertschek dan Niebel menjelaskan bahwa dalam penggunaan internet dengan positif akan meningkatkan produktivitas kerja perusahaan (Bertschek dan Niebel, 2016). Dari hasil penelitian Bertschek dan Niebel tersebut dikatakan memiliki hubungan antara penggunaan internet dan produktivitas kinerja perusahaan, sehingga menggunakan internet dengan baik dan produktif di kehidupan seharihari baik untuk belajar maupun bekerja akan memberikan keuntungan dan manfaat bagi setiap organisasi atau suatu perusahaan. Dengan hal ini tujuan BLC yang salah satunya di Taman Prestasi Surabaya juga untuk meningkatkan produktivitas penggunaan internet di Surabaya yang akan berpengaruh dalam produktivitas masyarakat itu sendiri baik secara individual maupun organisasional.

Dampak secara tidak langsung yang dirasakan terhadap organisasional yakni semangat kerja dari anggota organisasi tersebut seperti pada pelaksanaan program BLC yang selalu memberikan pelayanan terbaik untuk masyarakat seperti : (a) Sarana dan prasarana; (b) Tenaga pengajar yang disediakan oleh Diskominfo Kota Surabaya berjumlah 54 orang yang terbagi dari 53 instruktur dan 1 koordinator BLC (Mufliha, 2018). Sumber Daya Manusia memiliki fungsi yang penting dan salah satu modal yang berharga dalam pelaksanaan suatu program, hal itu disebutkan pada penelitian Palvia, Baqir dan Nemati bahwa Sumber Daya Manusia (SDM) merupakan salah satu fungsi yang berharga dalam pelaksanaan kebijakan atau suatu program (Palvia et al., 2018). Pada website resmi BLC, di Taman Prestasi Surabaya memiliki instruktur sebanyak 3 orang. Instruktur BLC tersebut lulusan dari universitas terkemuka dan lulusan dari jurusan yang relevan sesuai dengan pembelajaran yang diajarkan pada waktu pelatihan (Muryani dkk, 2017). Dinas Komunikasi dan Informatika Kota Surabaya merekrut instruktur tersebut dengan kualifikasi D3/D4/S1 Teknik Informatika atau Sistem Informasi, menguasai sistem Operasi Windows OS dan Linux OS dan menguasai materi yang ada di program pelatihan ini. BLC juga memiliki 3 divisi yaitu Divisi Internet, Divisi Design dan Divisi Office; (c) Pelatihan soft skill dan hard skill yang diberikan untuk tenaga pengajar; (d) Sertifikat bagi peserta setelah selesai melaksanakan program BLC; (e) melakukan pengawasan dan evaluasi oleh koordinator ke lokasi BLC dan meminta laporan harian dan bulanan dari instruktur yang bertugas. Laporan tersebut dikumpulkan instruktur ke koordinator BLC dan Dinas Komunikasi dan Informatika Kota Surabaya.

Laporan Pertanggungjawaban dari instruktur tersebut meliputi pembelajaran yang sesuai dengan jadwal yang telah ditetapkan, jumlah peserta dan melaporkan pemberian materi pelatihan. Laporan hasil pelaksanaan pembelajaran di BLC ini melalui whatsapp grup dan pada sistem monitoring BLC. Instruktur juga memberikan laporan berbentuk laporan pertanggungjawaban berbentuk soft file atau hard file.

Laporan hasil pembelajaran tersebut dapat membantu instruktur dalam mengetahui sejauh mana pencapaian pembelajaran atau pelatihan BLC terhadap peserta. Menurut buku dari Roestiyah yang dikutip oleh Slameto mendeskripsikan pengertian evaluasi yaitu: (a) Evaluasi adalah suatu proses mengkomunikasikan suatu informasi bagi pihak pelaksana dalam mengambil sebuah keputusan; (b) Evaluasi adalah kegiatan dalam mendapatkan beberapa data yang berhubungan dengan pelaksanaan program BLC seperti para instruktur dan hasil belajar 
peserta yang dapat mengembangkan program agar mencapai semua tujuan; (c) evaluasi juga merpakan suatu kegiatan untuk menilai seberapa jauh program telah berjalan seperti yang sudah direncanakan; (d) Evaluasi sebuah alat untuk mengetahui proses pelatihan dan pengembangan ilmu di BLC apakah sudah sesuai dengan yang diharapkan atau belum (Slameto,2001).

\section{Dampak Pada Masyarakat}

Broadband Learning Center di Taman Prestasi Surabaya adalah salah satu lokasi pelatihan dari 52 titik lokasi yang telah disediakan Pemerintah Kota Surabaya. Pelatihan komputer gratis ini diperuntukan bagi masyarakat baik yang membutuhkan bantuan dalam meningkatkan kemampuan dibidang teknologi maupun yang ingin belajar mulai dari nol karena kurang mampunya mengoprasikan teknologi. BLC ini tidak hanya berlaku untuk masyarakat Kota Surabaya saja tetapi masyarakat luar Kota Surabaya. Mereka dapat berkunjung atau menjadi peserta di BLC yang salah satunya terletak di Taman Prestasi Surabaya.

Pelatihan komputer gratis ini berdampak positif bagi masyarakat dan meningkatkan kepercayaan terhadap Pemerintah Kota Surabaya. Pemberian pelatihan gratis akan memberikan kesempatan kepada masyarakat atau peserta dalam mengembangkan kompetensinya tanpa mengkhawatirkan biaya pelatihan tersebut (Hermes et al., 2019). Pada program BLC ini memberikan pelatihan gratis untuk masyarakat dan tidak memandang usia, gender atau jenjang pekerjaan.

Kehadiran program BLC dapat mengubah pola pikir masyarakat bahwa penggunaan TIK sangat bermanfaat.Tetapi terdapat masyarakat yang menganggap pelatihan BLC hanya bermanfaat bagi siswa sekolah sehingga kurang meratanya kategori peserta dalam mengikuti program BLC, terutama pada ibu rumah tangga yang sebenarnya jika mengikuti pelatihan ini akan bermanfaat bagi peningkatan perekonomiannya (Febriany dan Fanida, 2015).

Program BLC yang salah satunya di Taman Prestasi Surabaya berupaya memberikan kualitas pelayanan yang baik untuk peserta atau masyarakat seperti melaksanakan pelatihan rutin dari hari Senin sampai Jumat dengan 5 sesi. Sesi 1 dari pukul 8.00-10.00 WIB, sesi 2 dari pukul 10.00-12.00 WIB, sesi 3 dari pukul 13.00-15.00 WIB dan khusus di hari Jumat dari pukul 13.30-15.30 WIB, sesi 4 dari pukul 15.00-17.00 WIB dan khusus dihari Jumat dari pukul 15.30-17.30 WIB, sesi yang ke-5 yaitu pada pukul 18.00-20.00 WIB. Pada sesi ke-4 dan ke-5 hanya ada di BLC Prestasi dan Grudo. Di hari Sabtu dan Minggu dibuka untuk layanan informasi hanya pada BLC Rumah Bahasa, BLC Taman Prestasi, BLC taman Flora, BLC Rusun Grudo.
BLC di Taman Prestasi Surabaya juga menyediakan fasilitas untuk menunjang pelaksanaan pembelajaran, tetapi masih terdapat beberapa kendala seperti kecepatan akses internet dan peserta tidak mendapatkan modul saat proses atau setelah pelatihan (Ulfa, 2016).

Dalam pelatihan terdapat dua konsep pelaksanaan pelatihan yaitu: (a) pemberian materi secara teoritik, yang dimana peserta diberikan modul materi sesuai silabus yang telah disusun sebelumnya; (b) pemberian materi secara praktik, yang dimana dari teori yang telah disampaikan secara tertulis atau berbentuk modul tersebut diaplikasikan atau dipraktikan. Dalam hal ini peserta mendapatkan fasilitas seperti komputer, jaringan internet sebagai menunjang pembelajaran, atau sarana prasarana lainnya (Notoatmodjojo,2003).

Berdasarkan penelitian Mufliha ditemukan beberapa kekurangan pelaksanaan dalam program BLC ini yaitu terdapatnya keluhan masyarakat seperti kurang tanggapnya para pelaksana program BLC dalam perbaikan fasilitas yang seharusnya juga diperhatikan karena mendukung dalam proses pelatihan berlangsung, dan instruktur yang tidak rutin memberikan catatan materi pelatihan. Tidak hanya keluhan dari masyarakat atau peserta BLC ternyata terdapat keluhan dari instruktur BLC seperti pelatihan hard skill yang kurang efektif karena terkendala sarana dan prasarana yang kurang memadai seperti komputer atau fasilitas lainnya yang diperlukan dalam pelatihan belum di upgrade (Mufliha, 2018).

\section{Dampak Pada Lembaga dan Sistem Sosial}

Pelatihan komputer salah satunya dilakukan untuk meningkatkan prestasi akademik dalam bidang TIK (Korucu dan Gunduz, 2011). BLC merupakan program pelatihan komputer gratis yang memberikan dampak pada lembaga pendidikan yang terbantu karena dapat mendorong motivasi dalam pembelajaran dibidang teknologi. Dengan program ini memberikan materi seperti Fun Programming bagi anak-anak dan materi lainnya disesuaikan untuk kebutuhan pelajar dari jenjang Sekolah Dasar (SD) sampai Sekolah Menengah Atas atau Kejuruan (SMA/SMK). Peserta BLC yang berjenjang SD dan SMP akan diberikan pelatihan yang sesuai dengan pelajaran di sekolah seperti menggunakan beberapa fitur di aplikasi Writer, Presentation and Spreadsheets Office (WPS Office) dan menuntun peserta dalam katergori tersebut untuk menggunakan internet dalam menyelesaikan tugas sekolah dan mengerjakan try out online (Vionita dan Rahaju, 2016). Dengan materi yang diberikan tersebut maka lembaga pendidikan terbantu dengan adanya program BLC yang dimana pelatihan ini sebagai pendidikan non formal. 
Dalam Undang-undang No. 20 Tahun 2003 Tentang Sistem Pendidikan Nasional bahwa pendidikan non formal ini diselenggarakan bagi masyarakat yang memerlukan layanan pendidikan sebagai pengganti, penambah dan pelengkap pendidikan formal, dan berfungsi dalam mengembangkan potensi peserta didik dengan penekanan dan penguasaan pengetahuan dan ketrampilan fungsional serta pengembangan sikap dan kepribadian professional.

Program BLC ini juga membantu mencerdaskan masyarakat agar dapat lebih produktif dalam penggunaan internet. Keproduktivitasan penggunaan internet atau teknologi dijelaskan oleh Batabyal and Nijkamp dalam jurnal tentang penyediaan TIK di Smart City. Smart City merupakan kota pintar yang memberikan informasi dan mengelola sumber daya secara efektif dan efesien (Wanto, 2017). Penelitian oleh Batabyal and Nijkamp tersebut menyatakan bahwa pemanfaatan TIK secara optimal dapat meningkatkan pertumbuhan perekonomian di kota (Batabyal \& Beladi, 2019). Maka dengan pelatihan ini juga diharapkan mampu memberikan optimalisasi dalam pemanfaatan TIK di Surabaya sehingga dapat membantu peningkatan di bidang ekonomi.

Dengan hal ini program BLC memberikan dampak juga di lembaga ekonomi tidak hanya di lembaga pendidikan. Contohnya seperti memberikan materi Internet For Business yang menjelaskan terkait pemasaran sosial media, marketplace lokal Surabaya dan Desain Grafis yang menjelaskan berbagai desain kemasan, poster, kartu nama, stiker, brosur. Dalam artikel blc.surabaya.go.id yang diterbitkan pada tanggal 23 November 2018 oleh admin BLC menerangkan bahwa program BLC ini bertujuan agar para pelaku UMKM Surabaya menuju UMKM yang ramah teknologi dan mengajak UMKM untuk bersinergi bersama dalam ekonomi digital. Ibnu sebagai instruktur BLC menjelaskan bahwa :

\section{"Materi yang disampaikan antara lain mengenai teknik mendesain kemasan produk, membuat laporan keuangan dengan menggunakan aplikasi perkantoran dan membuat video promosi produk. Para pelaku UMKM juga diarahkan untuk menggunakan tiga marketplace buatan arek Surabaya" (blc.surabaya.go.id).}

Sehingga dengan adanya pelatihan BLC ini juga berdampak pada sektor ekonomi karena dengan adanya pelatihan seperti yang dijelaskan pada website blc.surabaya.go.id memberikan manfaat dalam penjualan dan masyarakat dapat menerima hasil dari pelatihan tersebut.

\section{PENUTUP}

\section{Simpulan}

Berdasarkan hasil dalam penelitian berjudul evaluasi dampak program Broadband Learning Center di Taman Prestasi Surabaya ini dapat disimpulkan bahwa implementasi BLC di Taman Prestasi Surabaya selama ini memberikan dampak kepada setiap individu atau pesertanya, organisasi, masyarakat dan lembaga atau sistem sosial.

Masyarakat menerima salah satu program dari PT Telkom yang dihibahkan kepada Pemerintah Kota Surabaya. Program ini sebagai salah satu pelayanan publik dengan memberikan pelatihan komputer gratis. Broadband Learning Center ini dilaksanakan oleh Dinas Komunikasi dan Informatika Kota Surabaya sebagai salah satu usaha dalam mencapai Smart City yang menggunakan TIK dengan optimal serta Surabaya Multi Media City, dan mewujudkan cita-cita negara dalam mencerdasakan kehidupan bangsa. Dampak yang dirasakan setiap individu dalam program BLC adalah terbantunya peserta dalam meningkatkan kemampuan dalam bidang teknologi. Dengan kemudahan mendaftar dan tersedianya fasilitas yang memadai dirasakan setiap peserta BLC sehingga dapat menunjang dalam proses pembelajaran di BLC.

Fasilitas yang diberikan oleh Dinas Komunikasi dan Informatika Kota Surabaya yaitu tersedianya sarana prasarana dalam membantu proses pelatihan, instruktur yang telah diberikan pelatihan terlebih dahulu dan sesuai dengan kualifikasi dalam memberikan pembelajaran bagi peserta, sertifikat setelah peserta selesai dalam melaksanakan programnya dan adanya laporan pertanggungjawaban dari instruktur BLC kepada Koordinator dan Dinas Komunikasi dan Informatika Kota Surabaya sehingga mengetahui sejauh mana pelaksanaan BLC berjalan dan melakukan penilaian atau perbaikan dalam program yang ditujukan kepada masyarakat ini. BLC juga memberikan dampak pada lingkungan guru, PNS, UMKM dan lingkungan lainnya.

Dalam sebuah program selain memberikan dampak positif dan diharapkan bagi masyarakat, terdapat juga dampak yang tidak diinginkan yaitu adanya kecemasan orang tua dalam membiarkan anak-anaknya mengakses internet karena dengan itu dapat membuka situs-situs yang tidak diharapkan atau situs yang negatif. Pelaksanaan program BLC ini juga memiliki kendala seperti kurangnya motivasi masyarakat dalam melanjutkan setiap sesi pertemuan. Sehingga terdapatnya penurunan daftar hadir peserta BLC.

Program BLC memberikan dampak pada organisasional baik secara langsung maupun tidak langsung. Dampak yang dirasakan secara langsung dari program BLC ini membantu Pemerintah Kota Surabaya 
dalam menuju Surabaya Multi Media City yang merupakan kota berbasis Teknologi Informasi dan Komunikasi (TIK). Dengan pelaksanaan program BLC juga memberikan Surabaya penghargaan FutureGov Awards Asia Pasific di tahun 2013. Penghargaan data inclusion ini didapat melalui program BLC yang bertujuan mengatasi kesenjangan digital. Dampak secara tidak langsung pelaksana program BLC ini termotivasinya para pelaksana program BLC dalam memberikan pelayanan kepada masyarakat. Tetapi terdapat kekurangan dalam pelaksanaan program BLC yaitu kurangnya modul pembelajaran yang disediakan untuk peserta agar dapat dipelajari dalam proses pembelajaran atau selesai dalam melaksanakan pembelajaran di BLC dan beberapa fasilitas yang belum di upgrade.

Pelatihan komputer gratis ini juga berdampak pada masyarakat karena dengan program BLC yang salah satunya di Taman Prestasi ini, kepercayaan masyarakat terhadap pemerintah meningkat karena Pemerintah Kota Surabaya telah memberikan pelatihan yang bermanfaat tanpa dipungut biaya sedikitpun. Dengan pembelajaran yang dilaksanakan 5 sesi pada hari Senin hingga Jumat dan memberikan layanan informasi pada hari Sabtu hingga Minggu.

Dampak yang diberikan BLC ini juga berpengaruh pada lembaga pendidikan dan lembaga ekonomi. Karena dengan adanya pelatihan ini membantu masyarakat atau pelajar jenjang apapun dalam meningkatkan kemampuan di bidang teknologi. Lembaga pendidikan terbantu dengan adanya program BLC yang dimana pelatihan ini sebagai pendidikan non formal sehingga dapat membantu pelajar dalam meningkatkan prestasi belajarnya. Program BLC ini tidak hanya berdampak pada lembaga pendidikan saja tetapi berdampak pada lembaga ekonomi. Dengan adanya program ini pelaku UMKM terbantu dalam memperluas jangkauan pasar atau usahanya. Sehingga para pelaku UMKM Surabaya dapat menuju UMKM yang ramah teknologi dan bersinergi bersama dalam ekonomi digital.

\section{Saran}

Berdasarkan hasil kesimpulan, maka terdapat beberapa saran dari penulis untuk dapat dijadikan sebagai bahan masukan atau pertimbangan. Saran ini juga diperuntukan agar pelaksanaan program BLC mencapai tingkat keberhasilan dalam mencapai tujuan yang telah direncanakan. Saran tersebut meliputi :

1. BLC sebagai upaya dalam pelayanan publik membantu masyarakat dalam meningkatkan kemampuan di bidang teknologi diharapkan dapat lebih mensosialisasikan program ini secara berkala sehingga seluruh lapisan masyarakat mengetahui dampak setelah melakukan pelatihan di BLC.
2. Pelaksana program BLC diharapkan untuk dapat mengupgrade fasilitas yang rusak di setiap lokasi BLC salah satunya pada BLC Taman Prestasi Surabaya dan memberikan fasilitas tambahan salah satunya modul untuk pembelajaran atau setelah pelatihan selesai sehingga pelaksanaan pelatihan dapat berjalan dengan yang diharapkan.

3. Dinas Komunikasi dan Informatika diharapkan dapat menambah beberapa variasi materi lainnya dalam pelatihan di BLC agar minat masyarakat bertambah untuk melaksanakan pelatihan tersebut.

\section{REFRENSI}

Admin. (2018, November 23). UMKM Surabaya Belajar Jualan Online di BLC. Website Resmi Broadband Learning Center. Diakses dari Blc.surabaya.go.id.

Amanah, Istidha Nur. 2019. Pemanfaatan Literasi Digital di Kalangan Guru dan Pelajar di Surabaya. Radar Surabaya. (Online). (https://radarsurabaya.jawapos.com/read/2019/05/03/ 135212/78-persen-pelajar-surabaya-akses-internetuntuk-medsos. Diakses pada 10 Juli 2020)

Ariawantara, P. A. F. (2017). Peran Broadband Learning Center dalam community development. Masyarakat, Kebudayaan Dan Politik, 30(2), 162. https://doi.org/10.20473/mkp.v30i22017.162-173

Batabyal, A. A., \& Beladi, H. (2019). The optimal provision of information and communication technologies in smart cities. Technological Forecasting and Social Change, 147(March), 216220. https://doi.org/10.1016/j.techfore.2019.07.013

Bertschek, I., \& Niebel, T. (2016). Mobile and more productive? Firm-level evidence on the productivity effects of mobile internet use. Telecommunications Policy, 40(9), 888-898. https://doi.org/10.1016/j.telpol.2016.05.007

Eprilianto, Deby Febriyan dkk. 2019. Mewujudkan Integrasi Data Melalui Implementasi Inovasi Pelayanan Kesehatan Berbasis Teknologi Digital. JPSI (Journal Of Public Sector Innovations), 4 (1), 30-37.

European Commission. (2016). EU eGovernment Action Plan 2016-2020 - Accelerating the Digital Transformation of Government. COM(2016) 179 Final, 179, 11. https://ec.europa.eu/digital-singlemarket/en/news/communication-eu-egovernmentaction-plan-2016-2020-accelerating-digitaltransformation

Febriany,N.I., dan Eva.H.F. (2015). Evaluasi Corporate Social Responsibility Pt Telkom Divisi Regional V Jawa Timur ( Studi Pada Program Broadband Learning Center Di Rusunawa Grudo, Surabaya). Surabaya, Publika: UNESA Press 
Febriawan, Rizky Arya. 2018. Perancagan Desai User Interface Website Broadband Learning Center Pada Dinas Komunikasi dan Infromatika Pemerintah Kota Surabaya. Skripsi. responsitory.dinamika.ac.id

Hakim, A. R. (2015). Manajemen Pelatihan Komputer Dalam Program Corporate Social Responsibility PT.Telkom Untuk Menumbuhkan Minat Belajar Masyarakat di Broadband Learning Center Taman Prestasi Surabaya. Broadband Learning Center Taman Prestasi Surabaya, 4 No.1. https://jurnalmahasiswa.unesa.ac.id/index.php/jurna l-pendidikan-luar-sekolah/article/view/11306

Hermes, M., Albers, F., Böhnke, J. R., Huelmann, G., Maier, J., \& Stelling, D. (2019). Measurement and structural invariance of cognitive ability tests after computer-based training. Computers in Human Behavior, 93, 370-378. https://doi.org/10.1016/j.chb.2018.11.040

Hidayatullah, M. N. (2017). RESPON MASYARAKAT PEMUDA ISLAM TERHADAP PROGRAM BROADBAND LEARNING CENTER ( BLC) DI SURABAYA : STUDI KASUS BLC MENANGGAL.

Intruksi Presiden RI Nomor 3 Tahun 2003 Tentang Kebijakan dan Strategi Nasional Pengembangan $E$ Government.

Islamy, M. Irfan. 2007. Prinsip-prinsip Perumusan Kebijaksanaan Negara. Jakarta: Bumi Aksara.

Kaelan. 2010. Metode Penelitian Agama Kualitatif Interdisipliner .Yogyakarta: Paradigma.

Kamil, Mustofa. 2012. Model Pendidikan dan Pelatihan Konsep dan Aplikasi. Bandung : Alfabeta

Korucu, A. T., \& Gunduz, S. (2011). The effects of computer assisted instruction practices in computer office program course on academic achievements and attitudes toward computer. Procedia - Social and Behavioral Sciences, 15, 1931-1935. https://doi.org/10.1016/j.sbspro.2011.04.030

Kummitha, R. K. R. (2020). Why distance matters: The relatedness between technology development and its appropriation in smart cities. Technological Forecasting and Social Change, 157(April), 120087.

https://doi.org/10.1016/j.techfore.2020.120087

Listyanti, Agita Sukma. (2013, November 1). Surabaya Raih Future Gov Awards Asia Pasifik 2013. website resmi Kementrian Komunikasi dan Informatika Republik Indonesia Diakses dari Kominfo.go.id

Maarse. 1987. Implementasi Kebijakan.Terjemahan Gary R. Yusuf. Jakarta: Universitas Indonesia Press.

Miles, B. Mathew dan Michael Huberman. 1992. Analisis Data Kualitatif Buku Sumber Tentang Metodemetode Baru. Jakarta: UIP.

Mufliha. (2018). Evaluasi Program Broadband Learning
Center (Studi Tentang Efektivitas Dan Efisiensi Pada Program Broadband Learning Center Di Kota Surabaya). Jurnal Kebijakan Dan Manajemen Publik, 6(2), 1-11.

Mulyasari, M., \& Rosdiana, W. (2017). Dampak Program Broadband Learning Center (Blc) Di Kelurahan Dukuh Menanggal, Kecamatan Gayungan, Kota Surabaya. Publika, 5(6), 1-6.

Muryani, S., Anjarwani, P., Sasmita, L. D., \& Raharja, W. T. (2017). Service Quality in Public Sector Toward Surabaya Multi Media City ( Case Study: Broadband Learning Center Services in Taman Prestasi, Surabaya City ).

Nawawi, Hadari. 2000. Manajemen Sumber Daya Manusia Untuk Bisnis yang Kompetitif. Gajah Mada University Press: Yogyakarta

Noe, R. A., Hollenbeck, J. R., Gerhart, B., \& Wright, P. M. 2016. Fundamentals of Human Resource Management.

Notoatmodjo, Soekidjo. 2003. Pengembangan Sumber Daya Manusia. Jakarta: PT. Rineka Cipta.

Palvia, P., Baqir, N., \& Nemati, H. (2018). ICT for socioeconomic development: A citizens' perspective. Information and Management, 55(2), 160-176. https://doi.org/10.1016/j.im.2017.05.003

Perez, M., \& Gomez, J. M. (2012). Why Do People Use Social Networks? SSRN Working Paper, 11(2), 133.http://papers.ssrn.com/sol3/papers.cfm?abstract_ $\mathrm{id}=1989586$

Putri, Y. M. (2014). Model Pengembangan Program Corporate Social Responsibility (CSR) "Broadband Learning Center" (BLC) Pada PT.Telkom.

Rusmawati, Y., \& Safa'atillah, N. (2016). Pengaruh Pelatihan Broadband Learning Center (BLC) Terhadap Kompetensi Gur Sekolah Menengah Kejuruan (SMK) Swasta di Surabaya Barat. CEUR Workshop Proceedings, 13(1), 315-322.

Rusmawati, Y., \& Safa'atillah, N. (2017). Pengaruh Disiplin Kerja dan Pelatihan Broadband Leraning Center (BLC) Terhadap Kinerja Pegawai Negeri Sipil. II(2), 491-501.

Sekretaris. (2013, Januari 8). Broadband Learning Center (BLC) Sarana Pembelajaran IT Gratis untuk Warga Kota Surabaya. Website Dinas Komnikasi dan Informatika Kota Surabaya. Diakses dari Kominfo.surabaya.go.id

Slameto. 2001. Evaluasi Pendidikan. Jakarta: Bumi Aksara.

Solomon, E. M., \& Klyton, A. van. (2020). The impact of digital technology usage on economic growth in Africa. Utilities Policy, 67(July), 101104. 
https://doi.org/10.1016/j.jup.2020.101104

Sutarto, Joko. 2007. Pendidikan Nonformal. Konsep Dasar, Proses Pembelajaran \& Pemberdayaan Mayarakat. Semarang: UNNES PRESS

Ulfa, E. M. (2016). Pelaksanaan Program Broadband Learning Center ( BLC ) Oleh Dinas Kominfo Pemkot Surabaya Untuk Mewujudkan Surabaya Cyber City. 2(1), 29-55.

Undang-Undang Republk Indonesia Tentang Informasi dan Transaksi Elektronik Nomor 11 Tahun 2016 BAB II Pasal 4

Undang-Undang No.20 Tahun 2003 Tentang Sistem Pendidikan Nasional

Vionita, Nadila Agita dan Tjitjik Rahaju. 2016. Efektivitas Program Broadband Learning Center (BLC) di Eks. Wisma Barbara, Kupang Gunung, Kota Surabaya. Publika: UNESA Press

Wanto, Alfi Haris. 2017. Strategi Pemerintah Kota Malang Dalam Meningkatkan Kualitas Pelayanan Publik Berbasis Konsep Smart City. JPSI (Journal Of Public Sector Innovations), 2 (1), 39-43.

Wardana, Dian Meyga Kusuma. 2017. Kinerja Pelaksanaan Program Broadband Learning Center (BLC) di Kota Surabaya. Unair Press. Volume 5 No.1

Wibawa, Samodra Dkk. 1994. Evaluasi Kebijakan Publik. Jakarta: PT Raja Grafindo Persada.

Website LowonganKerja15.com, diakses pada 24 Desember 2020 